\title{
Designing New Funding Models for Russian Football Clubs
}

\author{
Ilia Solntsev \\ $\mathrm{PhD}$, Director of Sports Research Department \\ Associate Professor of Corporate Finance and Corporate Governance Department \\ $\underline{\text { ORCID }}$ \\ E-mail: ilia.solntsev@gmail.com \\ Plekhanov Russian University of Economics, Moscow, Russia \\ Financial University under the Government of Russian Federation, Moscow, Russia
}

Journal of Corporate Finance Research, Vol. 13, No. 4, pp. 59-73 (2019)

DOI: https://doi.org/10.17323/j.jcfr.2073-0438.13.4.2019.59-73

Received 19 July 2019 | Peer-reviewed 8 September 2019 | Accepted 3 December 2019 


\section{Designing New Funding Models for Russian Football Clubs}

\section{Abstract}

In Europe, most football clubs have long been positioned as business projects, which are active in financial markets and apply various funding tools. The 2018 FIFA World Cup inspired a new wave of interest in Russian football and created attractive conditions for applying new funding tools. The specifics of the economy surrounding sports development in Russia have led to a situation whereby most sports clubs depend on limited apportionments of budgetary funds, and require novel sources of additional funding for different development purposes, e.g. constructing stadiums, training grounds, youth academies and everyday operations.

The aim of this research is to examine the best foreign practice in the field of attracting funding by sports clubs and propose adaptations for Russian conditions. This work presents a practice-oriented review of the most modern funding tools used in football, and analyses the capital structure of European football clubs, their funding policies and preferences.

The competitive level of the European and Russian clubs, their relative financial capabilities, and their development prospects were considered, and the analytical mapping process ascribed prospective investment ratings to the Russian clubs. In a similar manner, recommendations as to how practical funding examples from European clubs may be adapted and followed in the Russian context are described. By comparison and contrast, likely candidates among Russian clubs for similar economic strategies are identified. The sources of information utilised for this process include annual reports from European football clubs, research studies, and academic articles, along with any available contextual information on Russian clubs.

The study was limited by the secrecy of reporting in Russian football and the weak financial position of most Russian clubs, which restricts their funding opportunities. However, despite the special development model of domestic Russian football and the harsh economic conditions, the proposals formulated in this work can be implemented into the practical activity of any club, regardless its scale and can contribute to improving financial sustainability, competitive results and the integrated development of Russian clubs. The methods proposed can act as a catalyst for the gradual corporatisation of Russian football clubs and will be of interest to investors, business analysts, economic scientists and football fans alike.

Keywords: bond interest rates, international financial markets, financial instruments, industry studies: sports JEL classification: G12, G32, Z23 


\section{Introduction}

If we assume that a football club is a fully-fledged business unit (which has been proven in practice globally), we may articulate that a standard set of instruments can be used to finance it [1]:

1) Internal (profit and depreciation)

2) External: debt and joint-stock capital

In this paper we will consider the above instruments taking into consideration the specifics of the football business.

Internal sources of revenue are generated in the course of the company's business operations. A football club's revenue traditionally consists of profits from the day of the match (ticket and season ticket sales, catering and merchandising), sale of media rights, and sponsorship agreements. The major individual feature of a football club's business is the dependence of all the above items on the match result which almost cannot be predicted. In the case of Russia, additional limitations include the weak development of the sports industry in general, the supporters' unreadiness to pay serious sums, and weak business management. In aggregate, all the above are reasons for the inability of the majority of clubs to generate serious earnings and, as a consequence, they require external sources of funding.

In order to finance investment projects and to cover the operating capital, companies use borrowed funds: bank credits, bonded loans, leasing, loans via a promissory note, etc. From an economic point of view, all these instruments are an unconditional obligation to repay the obtained amount and the pre-agreed remuneration by a specified date. As such, we will consider further the most popular debt instruments: bank credits and bonded loans as well as raising of the share capital through IPO.

\section{Debt instruments}

In general, irrespective of the instrument, the advantages of debt funding comprise the fact that it does not imply interference with the company management and gives an opportunity to save on income tax. Moreover, such instruments are characterised by a high value, and a range of covenants and support requirements.

According to UEFA [2] the net debt ${ }^{1}$ of the 20 most debt-laden European clubs exceeds $€ 4.7$ billion (table 1), and the total net debt of all clubs amounts to $€ 6.8$ billion.

The classical instrument of debt funding is credit. Taking into consideration the specifics of the football industry the most probable purposes for using this particular instrument of business financing are as follows: financing of capital investments (for example, construction of a stadium, academy, training grounds), or the refunding of formerly-raised borrowed funds. However, in practical terms an obligatory condition for the granting of credit is a security whose value should cover the principal debt, the interest, and the possible expenses of its fulfillment. This condition may become problematic for a football club. The central matter is that its key assets are intangible (in practical terms, the key asset of any club is its supporters) and its infrastructure (the stadium, training facility) have a low liquidity value.

Often, the raising of credit by a football club is related to a change of the club owner (see some examples below). Another prevalent situation is gaining a credit for construction of a stadium. So, the English club Tottenham Hotspur in 2016 started construction of its new home stadium. In order to fund the construction in 2017 the club raised a 5 -year credit granted by a banking syndicate (HSBC Bank, Goldman Sachs Bank and Bank of America Merrill Lynch) which totaled $£ 400$ million. A floating interest rate at LIBOR + 225-300 basis points was set for the credit, the security for which was the new stadium and the revenues related to it. In October of 2018, an increase of the credit value by $£ 100$ million was declared which happened because of the growth of the stadium's estimated cost. The stadium was subsequently constructed, the associated areas were furnished at the beginning of 2019, and on 3 April the first home match took place at the new stadium.

Securitisation is often used in the football business as a financing method. It implies that the club sells a part of its future revenues in advance and uses the money to construct a stadium [3]. Typical securitisation items are revenues from the sale of stadium naming rights or from the sale of premium class tickets and season passes. For example, before the new stadium of Stock City was opened in 1997 the stadium naming right had been sold to the company Britannia. Another example is the agreement of Arsenal with the company Emirates: apart from a sale of the naming rights, the agreement provided for the sale of the right to advertise on football jerseys, which were primary financing instruments behind the construction of their new stadium. In practice, several financial instruments may be applied. For example, as in construction of the Juventus stadium the following financing methods were established [4]:

1) a long-term partnership agreement with Sportfive Italia S.p.A. which got the exclusive right to sell the new stadium naming rights and a part of closed sky boxes and VIP seats. The term of the partnership is 12 years from the date of completion of the stadium's construction. The minimum amount due to Juventus under this agreement is 75 million Euro;

2) a credit agreements amounting to 60 million Euro. The credits' period is 12 years. The sources of

\footnotetext{
${ }^{1}$ As defined by UEFA, the net debt is calculated as the aggregate value of net borrowings (bank overdrafts, bank credits and other loans, accounts payable to the group companies and other related entities after deduction of cash and its equivalents), net balance of payments as a result of the club players' transfers (the difference between the accounts receivable concerning players' transfers and accounts payable concerning players' transfers) and accounts payable to social funds and tax authorities (long-term).
} 
repayment are the revenues from Sportfive and gate revenues. The credit is secured by mortgage and the guarantee issued by Instituto per il Credito Sportivo;

3) 3) a contract for the construction of a shopping center in the territory immediately adjacent to the stadium by Nordiconad Group. The contract value amounted to 20.25 million Euro.

An interesting situation has come about in Turkish football. Apart from raising funds in the stock market, Turkish football clubs, especially the "Big Four" (Besiktas, Fenerbahce, Trabzonspor and Galatasaray), operated ac- tively in the debt market as well. At the beginning of 2019 the total debt owed to banks by Turkish clubs amounted to 11 billion Turkish liras ( $\$ 2$ billion). Due to economic decline in the country, the clubs could not repay the majority of loans, and as a result even the national championship was under challenge.

However, at the beginning of January of 2019 at the meeting of the heads of Super League members, representatives of the country bank association, and the president of the Turkish Football Federation, a decision to grant financial assistance to these clubs was adopted.

Table 1. European football clubs with the highest net debt

\begin{tabular}{|c|c|c|c|c|c|}
\hline$\#$ & Club & Country & $\begin{array}{l}\text { Net debt in financial } \\
\text { year } 2017, € \text { million }\end{array}$ & $\begin{array}{l}\text { Growth of net } \\
\text { debt year/year }\end{array}$ & $\begin{array}{l}\text { Net debt to } \\
\text { revenue ratio }\end{array}$ \\
\hline 1 & Manchester United & England & 459 & $-18 \%$ & $0.7 \mathrm{x}$ \\
\hline 2 & Inter & Italy & 438 & $44 \%$ & $1.6 \mathrm{x}$ \\
\hline 3 & Atletico & Spain & 391 & $44 \%$ & $1.4 \mathrm{x}$ \\
\hline 4 & Juventus & Italy & 289 & $2 \%$ & $0.7 \mathrm{x}$ \\
\hline 5 & Milan & Italy & 272 & $30 \%$ & $1.4 \mathrm{x}$ \\
\hline 6 & Benfica & Portugal & 269 & $-13 \%$ & $2.1 \mathrm{x}$ \\
\hline 7 & Galatasaray & Turkey & 229 & $13 \%$ & $2.3 \mathrm{x}$ \\
\hline 8 & CSKA & Russia & 229 & $18 \%$ & $3.4 \mathrm{x}$ \\
\hline 9 & Liverpool & England & 225 & $-17 \%$ & $0.5 \mathrm{x}$ \\
\hline 10 & Roma & Italy & 219 & $-14 \%$ & $1.3 \mathrm{x}$ \\
\hline 11 & Fenerbahce & Turkey & 215 & $44 \%$ & $1.8 \mathrm{x}$ \\
\hline 12 & Valencia & Spain & 213 & $-12 \%$ & $2.1 \mathrm{x}$ \\
\hline 13 & Sunderland & England & 185 & $3 \%$ & $1.3 \mathrm{x}$ \\
\hline 14 & Porto & Portugal & 177 & $10 \%$ & $1.8 \mathrm{x}$ \\
\hline 15 & Lyon & France & 174 & $-31 \%$ & $0.9 \mathrm{x}$ \\
\hline 16 & Schalke 04 & Germany & 158 & $21 \%$ & $0.7 \mathrm{x}$ \\
\hline 17 & Besiktas & Turkey & 154 & $8 \%$ & $1.0 \mathrm{x}$ \\
\hline 18 & Monaco & France & 147 & $13 \%$ & $1.0 \mathrm{x}$ \\
\hline 19 & Middlesbrough & England & 146 & - & $1.0 \mathrm{x}$ \\
\hline 20 & Copenhagen & Denmark & 143 & $10 \%$ & 2.7 \\
\hline $\begin{array}{l}\text { Sum/ } \\
\text { weighted } \\
\text { average }\end{array}$ & & & 4,731 & $5 \%$ & $1.2 \mathrm{x}$ \\
\hline
\end{tabular}

Source: report of UEFA Club Licensing Benchmarking Report, Financial Year 2017 
Table 2. Circulated bonds of European football clubs

\begin{tabular}{|c|c|c|c|c|c|c|}
\hline Club & Country & Currency & Coupon & Date of placement & Maturity date & Issuing volumes \\
\hline Arsenal & England & GBP & 5.14 & 13.07.2006 & 01.09 .2029 & $210,000,000$ \\
\hline Arsenal & England & GBP & 1.40 & 13.07.2006 & 01.09 .2031 & $50,000,000$ \\
\hline Inter & Italy & EUR & 4.88 & 14.12 .2017 & 31.12 .2022 & $300,000,000$ \\
\hline Hertha & Germany & EUR & 6.50 & 31.10 .2018 & 08.11 .2023 & $40,000,000$ \\
\hline Juventus & Italy & EUR & 3.38 & 13.02.2019 & 19.02.2024 & $175,000,000$ \\
\hline
\end{tabular}

Source: comprised by the author on the basis of Bloomberg data

When it comes to examples of crediting Russian football clubs, there are extremely few of them. Neither are they to be easily discovered in public, the activity of almost all clubs being financed directly by shareholders or sponsors. One of the most recent examples of raising funds is the credit obtained by CSKA from Vnesheconombank (VEB). According to $\mathrm{RBC}^{2}$ in March of 2013 VEB granted to CSKA a credit line for $\$ 280$ million in order to build a new stadium on the security of 684 shares of the football club (24.8\%). In June of 2013 VEB signed an agreement for raising \$230 million from the Bank of America, Sumitomo Mitsui Finance Dublin Limited and Sumitomo Mitsui Rus Bank to finance construction of a stadium for CSKA. According to the report made by Bluecastle Enterprises in May of 2014, a supplementary agreement to the shares security agreement was concluded. As a security of the credit VEB obtained from CSKA 2,112 shares, i.e. the security increased up to $76.4 \%$ of the football club shares. Another popular debt funding instrument is the issuing of bonds. The main parameters informing their use are the amount of bonds issued, nominal value, coupon value, coupon payment frequency and the bond maturity period. The main advantages of bonded loans are as follows:

- fundraising for a long-term period;

- $\quad$ an opportunity to attract a wide range of investors;

- independence of an individual creditor;

- an opportunity of operative administration of the debt structure by conducting operations in the secondary market;

- more flexible forms of security.

It should be taken into consideration that a long preparation process precedes the actual placement of bonds and among other things it implies recruitment of external consultants. Besides, account must be taken of the fact that placement of a bond entails disclosure of full information on the company operations which is not always acceptable for a modern football club.

According to the data, as of March 31, 2019 there were several bond issues in circulation made by football clubs which are available to a wide range of investors. Their issuers are football clubs of England, Italy and Germany of the leading European Championships (table 2).

One of the first and best-known examples of bond placement by a football club is Eurobonds, issued by Arsenal Football Club.

In the middle of 2006 the club placed two tranches of secured bonds, whose total value was $£ 260$ million. The first issue, amounting to $£ 210$ million, was placed with a fixed coupon rate of $5.14 \%$ per annum to be paid in equal shares biannually (Bloomberg ticker - AFCPZ 5.1418 09/01/29, ISIN - XS0261374200). The par value of a bond is $£ 50,000$. The depreciation repayment structure is envisioned for it. According to this, the investor is paid a predetermined part of the bond par value on each second date of coupon payment starting from the first coupon payment. For the second issue, which amounts to $£ 50$ million, a floating coupon rate is provided. Its value is defined for the next coupon period by the following formula: a 3-months LIBOR rate in $£+55$ basis points (up to September of 201322 basis points were added to the LIBOR rate) (Bloomberg ticker - AFCPZ 0 09/01/31, ISIN - XS026137454). The par value of a bond of this issue also amounts to $£ 50,000$, however, in accordance with the depreciation structure the investor gets a part of the par value only starting from 2029. The money raised in the process of bond placement was used to refinance bank loans related to engineering and construction of the Emirates Stadium.

A new stage of bond placement by football clubs took place at the end of 2017 .

In December, the Italian football club Inter offered 5-years secured bonds in Euro to investors with a fixed coupon of 4.875\% (Bloomberg ticker - INTERM 4 7/8 12/31/22, ISIN - XS1739592142). The legal entity Inter Media and Communication S.p.A (which is the only manager and operator of media, broadcasting and sponsor business of the football club) was the bond issuer. The club managed to raise $€ 300$ million which was used mainly to refund the club's existing debt. 
At the end of 2018 the German club Hertha also enetered the bond market, placing $€ 40$ million of the senior unsecured debt (Bloomberg ticker - HERTHA 6 1⁄2 11/08/23, ISIN - SE0011337054). In that case the club was borrowing funds for the following purpose:

- complete or partial redemption of debt;

- payment of the penalty related to termination of contracts with Cortland Investors S.à r.l.;

- financing of expenses related to placement of bonds;

- financing of the club's operations.

The latest example of a successful placement of bonds by a football club is the senior unsecured debt of the Italian club Juventus (Bloomberg ticker - JUVEIM 3 3/8 02/19/24, ISIN - XS1915596222). In February of 2019 the issuer raised $€ 175$ million, offering 5 -year bonds in Euro to a wide range of investors with a fixed coupon of $3.625 \%$, to be paid once a year. Unlike the previous examples, in this case Juventus came into the debt market in order to obtain funds to finance the club's current operations instead of refinancing the existing debt.

However, the high degree of uncertainty of football results, financial indicators' volatility, and a lack of solid experience in interaction with financial instruments, all result in the fact that football clubs have to offer a high premium in order to raise the necessary funds when they enter the debt market.

Another important factor for debt instruments is the low amount of coverage of football clubs by rating agencies. This impedes assessment of risks of investment in the instruments of a certain issuer in accordance with the developed rating scale.

The credit rating is an opinion of a rating agency (national or international) on the issuer's business solvency or creditworthiness. At the moment there are 3 international agencies (Fitch, S\&P and Moody's) whose ratings are generally accepted as illustrating the risks of investment when featured in a particular debt instrument .
Usually a rating is assigned to each particular bond issue and this rating may differ upwards and downwards in comparison to the issuer's rating. This is due to the specific parameters of the issue including the debt seniority, level of debt security, etc.

Not a single agency assigned ratings to 2 out of 5 issues circulating in the market (JUVEIM 3 3/8 02/19/24 and HERTHA 6 1/2 11/08/23), and Inter's issue (mentioned above) was assigned "BB-" rating by S\&P agency, two Arsenal's issues have investment ratings "ВBВ" и “А-" assigned by Fitch and S\&P respectively (table 3 ).

First of all, an absence of ratings means that the cost of raising funds using debt instruments increases for the issuer.

Wins and losses in the Champions League at the beginning of 2019 (which influenced the dynamics of the club shares) resulted in a high volatility of Eurobonds with a maturity date in 2024 as well. For 2 months these bonds were traded in the wide range of $95-99 \%$ of the par value and the yield to maturity, which amounts to $4.5 \%$ at a moment, in mid-April returned to $3.7-3.8 \%$, which is a rare eventuality for such instruments.

Also an important point for the issuer as well as for the investor is the existence of call options, i.e. an opportunity for a club to redeem bonds from the market at a certain moment at a predetermined price. On the one hand, the existence of call options potentially limits the duration of the issue and consequently reduces the interest rate risk for the investor. On the other hand, its existence leads to a limited potential for the growth of bond quotations and there arises a risk that the investor will have no opportunity to place money at the same rate when exercising the call option.

Football clubs use this instrument extensively because they presume that while the bonds are in circulation their credit quality improves and there will be an opportunity to refinance the debt at terms more favourable for the club. It therefore influences the mechanism of evaluation of the issue market value.

Table 3. Data on the credit ratings of outstanding bonds of European football clubs ${ }^{3}$

\begin{tabular}{|c|c|c|c|c|c|c|}
\hline Ticker & ISIN & Issuer & Fitch & S\&P & Moody's & Average rating \\
\hline AFCPZ 5.1418 09/01/29 & XS0261374200 & Arsenal & $\mathrm{BBB}$ & A- & - & $\mathrm{BBB}+$ \\
\hline AFCPZ 0 09/01/31 & XS026137454 & Arsenal & $\mathrm{BBB}$ & A- & - & $\mathrm{BBB}+$ \\
\hline INTERM 4 7/8 12/31/22 & XS1739592142 & Inter & - & $\mathrm{BB}-$ & - & - \\
\hline HERTHA 6 1/2 11/08/23 & SE0011337054 & Hertha & - & - & - & - \\
\hline JUVEIM 3 3/8 02/19/24 & XS1915596222 & Juventus & - & - & - & - \\
\hline
\end{tabular}

Source: comprised by the author on the basis of S\&P, Fitch and Moody's data

3 Source: compiled by the author on the basis of data provided by rating agencies S\&P, Fitch and Moody's 
So, the structure of issue of Eurobonds by Inter implies the possibility to redeem the bonds on any date after 31.12 .2019 at the price of $102.438 \%$ of the par value, after 31.12.2020 - at 101.219\% and after 31.12.2021 - at 100\%. According to Bloomberg (as of April 15 ${ }^{\text {th }} 2019$ ) the bonds were traded at $102.619 \%$ of the par value. This makes it necessary to calculate the issue profitability on the basis of the nearest call option date, since in less than a year the bonds may be redeemed at a lower price than the current market quotation.

In case of bonds placement the crucial question is defining the coupon rate at which the club may raise funds. Here the risk-profitability ratio enters into the foreground.

The key parameter which helps to assess the issuer's credit risk is the credit rating. Precisely the assumption of the rating which may be assigned to Russian clubs will help to define the rate at which they will be able to raise funds.

Unfortunately, coverage of football clubs by rating agencies is extremely limited at present. One of the latest documents in this sphere is the methodology of assigning ratings to football clubs developed in 2018 by Fitch [5] agency which takes into consideration the following factors (Key Rating Drivers):

- League Business Model - Revenue Risk: the agency analyses the league strength, revenue structure, quality of national TV contracts, players' wage pattern, popularity and historical fan support, opportunities for growth, and control over the clubs;

- Franchise Strength - Revenue Risk: the team's ability to generate cashflow;

- Facility Infrastructure Development and Renewal: the agency analyses the club's opportunities for maintenance, reconstruction, and modernisation of infrastructure facilities;

- Debt Structure: Fitch analyses the debt structure, terms of repayment of obligations, sufficiency of liquidity and limits for increase of the debt load; and

- Financial Profile: the agency evaluates historical and projected cash flows of the club necessary for operating expenses.

On the basis of analysis of these indicators the rating agency includes the football club in one of 3 groups (Stronger, Midrange, Weaker) and assigns a credit rating to it.

The agency S\&P [6] uses a similar approach. In 2014 it offered the model of the Virtual Credit League where football clubs were ranked on the basis of 24 financial indicators arranged into 3 sections: business operations, solvency, and liquidity. In each of those sections a club was assigned one of 4 categories: top, above average, below average, and minimum.

It should be noted that not a single methodology detailed thus far offers the list of indicators used for assessment. Only a part of them is mentioned: operating income margin, return on equity, asset turnover, total debt to equity ratio. Also, absence of special indicators which characterises special aspects of the football business stands out. For these purposes, papers dedicated to the development of criteria for football clubs' performance efficiency and business solvency may be used [7,8]. Also in this respect the rules of UEFA financial fair play are critical [9].

Thus, on the basis of the existing methodologies of Fitch and S\&P, and in accordance with relevant research, a proprietary methodology of credit ratings assignment to football clubs in three categories may be developed (table 4).

Table 4. Criteria for building up the credit ratings of football clubs

Stronger Midrange Weaker

Income and expenses, liquidity

\begin{tabular}{|c|c|c|c|}
\hline $\begin{array}{l}\text { Existence of income items } \\
\text { exceeding } 30 \% \text { of revenue }\end{array}$ & $\begin{array}{l}\text { The revenue is diversified } \\
\text { maximally and no single } \\
\text { income stream exceeds } \\
30 \% \text { of overall revenue }\end{array}$ & $\begin{array}{l}\text { The revenue is diversified, } \\
\text { one income item is } \geq 40 \% \\
\text { of overall revenue }\end{array}$ & $\begin{array}{l}\text { Existence of income items } \\
\text { exceeding } 30 \% \text { of revenue }\end{array}$ \\
\hline Financial result & $\begin{array}{l}\text { Net profit for the previous } \\
3 \text { seasons }\end{array}$ & $\begin{array}{l}1 \text { loss-making season out } \\
\text { of three previous ones }\end{array}$ & $\begin{array}{l}2 \text { (and more) loss-making sea- } \\
\text { sons out of three previous ones }\end{array}$ \\
\hline Salary-to-revenue ratio & Within $60 \%$ & Within $70 \%$ & $>70 \%$ \\
\hline Current liquidity & Current liquidity ratio $>1$ & & Current liquidity ratio $<1$ \\
\hline
\end{tabular}

Debt load

$\begin{array}{lll}\text { Net debt } & \begin{array}{l}\text { Within 70\% of gross } \\ \text { income }\end{array} & \begin{array}{l}\text { Within 100\% of gross } \\ \text { income }\end{array}\end{array}$




$\begin{array}{llll} & \text { Stronger } & \text { Midrange } & \text { Weaker } \\ \begin{array}{lll}\text { Profit level in relation to } \\ \text { debt servicing expendi- } \\ \text { tures }\end{array} & \begin{array}{l}\text { No more than 50\% of } \\ \text { net profit is used for debt } \\ \text { servicing }\end{array} & \begin{array}{l}\text { No more than } 70 \% \text { of } \\ \text { net profit is used for debt } \\ \text { servicing }\end{array} & \begin{array}{l}\text { Over 70\% of net profit is used } \\ \text { for debt servicing }\end{array}\end{array}$

Sufficiency of cash flows ability to cover interest payments as well as payments aimed at principal redemption

Ratio of repayment period and asset life

A free cash flow is sufficient for payment of interest as well as for payments aimed at principal redemption
Repayment period does not exceed the asset life
Repayment period is comparable with the asset life
A free cash flow is not enough for payment of interest and for payments aimed at principal redemption

Repayment period exceeds the expected asset life

\section{Business operations}

Stadium utilisation at

home matches

$>80 \%$

$60-80 \%$

$<60 \%$ $\begin{array}{ll}\text { Relations with supporters } & \begin{array}{l}\text { No conflicts between shareholders, club management } \\ \text { and supporters }\end{array}\end{array}$

Financial fair play of UEFA

Absence of UEFA sanctions/remarks in the area of financial fair play in the previous 3 seasons
Existence of conflicts between shareholders, club management and supporters

Absence of UEFA sanctions/ remarks in the area of financial fair play in the previous 3 seasons

The result is below the $5^{\text {th }}$ place in the home championship and absence of matches in European Cups
Top-3 in the home championship, and

Competitive result participation in the Champions League group stage

\section{Possession of its own}

Own stadium stadium not "older" than 10 years
Top-5 in the home championship, and participation in the Europa League group stage
Possession of its own

stadium not "older" than Renting a stadium

Table 5. Risk assessment of investing in Russian football clubs

\begin{tabular}{|c|c|c|c|}
\hline & Income and expenses & Business operations & Debt load \\
\hline Stronger & - & Zenit & - \\
\hline Midrange & $\begin{array}{l}\text { Spartak } \\
\text { Zenit }\end{array}$ & $\begin{array}{l}\text { Spartak } \\
\text { CSKA } \\
\text { Krasnodar }\end{array}$ & $\begin{array}{l}\text { Spartak } \\
\text { Zenit } \\
\text { Lokomotiv } \\
\text { Krasnodar }\end{array}$ \\
\hline
\end{tabular}

$\begin{array}{llll} & \text { CSKA } & & \\ \text { Weaker } & \text { Lokomotiv } & \text { Lokomotiv } & \text { CSKA } \\ & \text { Krasnodar } & & \end{array}$

Source: compiled by the author on the basis of the data of Fitch Ratings, Fitch Solutions, the report A Complex Research of Economics of Russian Football, Season 2018/2019 made by PwC 
It should be noted that debt load indicators are controlled individually by UEFA within the 'financial fair play' regulations. In particular, licensing regulations comprise such indicator as debt sustainability - where the relevant debt should not exceed 30 million Euro and the sevenfold mean value of the relevant result in 2 previous periods. The relevant debt is calculated as net debt minus the amount owed, correlated directly to construction, or significant modification of the stadium and/or training facilities since the date of debt incurrence (and up to 25 years after a corresponding asset is declared ready for use). The relevant result for the reporting period is calculated as the sum of the gross income (in accordance with the breakeven calculation) and the net result of retirement and purchase of player registrations minus the overall operating expenses (in accordance with the break-even calculation). Additionally, the net debt should not exceed $100 \%$ of the gross income.

On the basis of the presented criteria, the credit ratings of Russian football clubs may be articulated. The classic structure of such ratings used by the leading agencies implies over 20 stages: from D (default on obligations) to AAA (the lowest credit risk expectations, an extremely high capability to discharge financial obligations). However, for an accurate evaluation, detailed financial information is necessary which is unavailable to Russian clubs. Patchy data is available concerning certain leading clubs: Spartak, Zenit, CSKA, Lokomotiv, and Krasnodar are examples. Apart from that, there is no data at all on the key subject - the debt load value. Obviously, and unfortunately, none of the clubs concerned can have an investment rating (from BBB-). The main reason for this is low revenue diversification: the lion's share of income goes to sponsors who are often affiliated with the club owners, while the share of income from sale of TV rights is extremely low. The majority of clubs remain loss-making and perform poorly in European Cups. There are also specific problems: Spartak is known for its uneasy relations with shareholders and supporters, while CSKA still experiences serious problems with a large debt load related to the funding of stadium construction. Lokomotiv and Krasnodar encountered problems in the area of financial fair play. Another problem for Lokomotiv is their outdated stadium. For the other 4 clubs modern infrastructure is an advantage. Match attendance and match day revenues of clubs such as Zenit, Spartak, and Krasnodar have grown significantly in recent years, thus reducing the share of the main revenue item - sponsorship agreements. Therein, in accordance with requirements of financial fair play, those agreements were arranged into several agreements, thus reducing (although partially in a technical way) the dependence on one sponsor. On the basis of the existing data the approximate assignment of the five leading clubs of the Russian Premier League to three rating groups is stated (see table 5).

In accordance with the proposed methodology these clubs may be assigned the following ratings:

- Zenit - "BB”

$$
\begin{array}{ll}
- & \text { Spartak - “BB-” } \\
- & \text { Krasnodar - "B” } \\
- & \text { CSKA - “B” } \\
- & \text { Lokomotiv - "B-" }
\end{array}
$$

It is important to note that clarification of financial information and data on debt load may significantly influence the final rating.

Calculation of the rate of return which the clubs have to offer to investors is possible on the basis of evaluation of the potential premium of marketable bonds. As an example we use Eurobonds of the Italian club Inter (Bloomberg ticker - INTERM 4 7/8 12/31/22, ISIN - XS1739592142) nominated in Euro with the rating of "BB-".

According to Bloomberg as of April 30, 2019 the bonds were traded with a yield to maturity of $4 \%$. On the basis of market practice we know that the premium of yield for one rating rank comprises on average 20 -30 basis points depending on the currency, the issuer's industry, and other factors. Taking into consideration the abovementioned special features of football clubs and the fact that placement has been made in "convertible" currency, we may assume that the premium for 1 rank of the rating may be valued at 25 basis points.

Thus, the fair yield of 4-year Zenit's bonds (rating "BB") nominated in Euro may be considered 3.5\%, Spartaks' bonds - 4\%, both CSKA's and Krasnodar's (rating "B") $4.5 \%$, and Lokomotiv's (rating "B-") - 4.75\%.

However, Russian clubs have to raise funds in the national currency. First of all, it helps to avoid exposure to foreign currency when the major part of revenues is in rubles and expenses related to the debt servicing are in a foreign currency. Additionally, it is difficult to assess the prospective demand for Eurobonds from foreign investors (actual and potential) in Russian football clubs. At the same time, there are attractive terms for investors in the Russian market and it helps to attract not only supporters of a team, but also classic investors which intend to gain profits in the stock market.

In order to evaluate the rate at which the clubs will be able to raise funds in rubles one can compare swap rates in Euro and rubles. In this case the yield to maturity in rubles should equal the sum of the yield in Euro and the spread between the ruble and Euro swaps for a comparable period (formula 1 ).

$\mathrm{R}_{\text {rub }}=\mathrm{R}_{\text {eur }}+\left(\mathrm{r}_{\text {rub }}-\mathrm{r}_{\text {eur }}\right)$,

where:

$\mathrm{R}_{\text {rub }}$ - borrowing rate in rubles;

$\mathrm{R}_{\text {eur }}$ - borrowing rate in Euro;

$\mathrm{r}_{\mathrm{rub}}$ - rate of ruble swaps;

$\mathrm{r}_{\text {eur }}$ - rate of Euro swaps.

According to figures provided by Bloomberg as of April 30,2019 the rate of 4-year swaps in Euro amounted to $(-0.05 \%)$, in roubles - to $8.52 \%$. Inserting this data into the right part of equation (1) and using the figures for 
the Euro borrowing rate calculated above for each club, the fair yield of 4-year ruble bonds (the left part of the equation) for Zenit may be assessed at $12.07 \%$, for Spartak - $12.57 \%$, for both CSKA and Krasnodar - 13.07\%, and for Lokomotiv - $13.32 \%$.

The most effective and frequently used method of assessment of the prospective required bond yield (depending on the investment period) is based on calculating the premium at which the issuer's bonds are traded. This is calculated with respect to the sovereign bonds curve (in this case - federal bonds with fixed and variable coupon income (OFZ).

According to Bloomberg (as of April 30, 2019) the yield of OFZ series 26225 - with a maturity date in August of 2023 (ISIN - RU000A0JU4L3) amounted to $7.83 \%$, which implies a yield spread of 4 -year bonds for the football clubs calculated above from 424 to 549 basis points.

The most popular period of bond placement is from 1 to 5 years duration. For further calculations we assume that the bond yield of the football club for each placement period ( 1 year, 2 years, 3 years, 4 years, and 5 years) should equal the yield of OFZ with a similar maturity period increased by the spread calculated above.

According to figures provided by Bloomberg as of April 30, 2019 the OFZ with maturity dates in 2020-2024 were traded with the yield of $7.46 \%$ to $8.00 \%$ (table 6). Thus, the dependence between the maturity of bonds and the possible yield may be represented as follows (table 7).

Thus, taking into consideration all the risks inherent in the sports industry, and in comparison to the credit cost, bonds may be a cheaper instrument. Besides, use of bonds does not result in loss of management. They are characterised by predetermined cost and period, which provides for certainty of financial planning. Additionally, there is no dependence on a particular creditor, and there is an opportunity to manage the debt structure by operations in the secondary market. Apart from the necessity to disclose full information on the club operations, and despite high time, cash, and labour costs, the drawbacks of bond placement comprise compulsory regular payments irrespective of the club performance and a significant increase of financial risk.

In the cases of Spartak, Zenit, and Lokomotiv the bond issuer may be one of their shareholders or sponsors.

Table 6. Selected data on the yield of OFZ as of 30.04.2019
Obviously, the rate will be significantly lower, but the terms on which the money will be transferred to the club are also important. For example, sponsorship agreements are of the maximum value and scarcely meet the criteria of financial fair play. Additionally, the bond issuer should disclose the designated use of funds - those conventional investors who are most likely to buy bonds of an entity such as Lukoil are less likely to be as enthusiastic about financing Spartak.

A successful bond placement offers the club great opportunities for further use of financial instruments and has a positive impact on the brand value. However, for the majority of clubs this instrument is unavailable because it requires great cash costs related to placement, a long-term and favourable credit history of the club, and involves meeting the severe financial requirements of investors. Therefore, taking into consideration the purpose of the present paper (the development of recommendations for raising funds by Russian football clubs) special attention should be given to another specific feature of football - that is, the mini-placement of bonds for the club supporters.

The football club Hamburger in autumn of 2012 successfully placed its bonds among supporters for approximately $€ 12.5$ million for the construction of a new children and youth school [3]. Another German club, Köln, faced financial difficulties due to its placement in the second division. In order to overcome these challenges, it declared an issue of bonds for $€ 10$ million in August of 2012 and offered them to supporters. It was the second case in history when supporters helped Köln to stay afloat by means of buying such bonds (the first case took place in 2005, and in summer of 2011 the club redeemed the bonds).

In recent years this method of financing club activity has increased in popularity. The reason for that, among other things, is the creation of special investment platforms.

For example, the global sports investment company Tifosy, apart from classic sports consultancy services, offers its clients certain fundraising services. The company acts as a financial consultant at all stages of fundraising, and takes on the role of an investment bank when classic bonds are placed [10].

According to Tifosy, in 2018 four European football clubs made use of its services and managed to raise in the region of $€ 10$ million (see table 8).

\begin{tabular}{|c|c|c|c|}
\hline Period & OFZ series & ISIN & Yield \\
\hline 1 year & 26214 & RU000A0JTYA5 & $7.46 \%$ \\
\hline 2 years & 26205 & RU000A0JREQ7 & $7.65 \%$ \\
\hline 3 years & 26209 & RU000A0JSMA2 & $7.80 \%$ \\
\hline 4 years & 26215 & RU000A0JU4L3 & $7.86 \%$ \\
\hline 5 years & 26227 & RU000A1007F4 & $8.00 \%$ \\
\hline
\end{tabular}

Source: compiled by the author on the basis of Bloomberg data 
Table 7. Estimation of the potential level of return on bonds of Russian football clubs, depending on the maturity

\begin{tabular}{|c|c|c|c|c|c|c|c|c|}
\hline Club & Rating & Return & $\begin{array}{l}\text { Spread of } \\
\text { OFZ }\end{array}$ & 1 year & 2 years & 3 years & 4 years & 5 years \\
\hline Zenit & BB- & $12.07 \%$ & $4.24 \%$ & $11.70 \%$ & $11.89 \%$ & $12.04 \%$ & $12.10 \%$ & $12.24 \%$ \\
\hline Spartak & BB & $12.57 \%$ & $4.74 \%$ & $12.20 \%$ & $12.39 \%$ & $12.54 \%$ & $12.60 \%$ & $12.74 \%$ \\
\hline Krasnodar & B & $13.07 \%$ & $5.24 \%$ & $12.70 \%$ & $12.89 \%$ & $13.04 \%$ & $13.10 \%$ & $13.24 \%$ \\
\hline CSKA & B & $13.07 \%$ & $5.24 \%$ & $12.70 \%$ & $12.89 \%$ & $13.04 \%$ & $13.10 \%$ & $13.24 \%$ \\
\hline Lokomotiv & B- & $13.32 \%$ & $5.49 \%$ & $12.95 \%$ & $13.14 \%$ & $13.29 \%$ & $13.35 \%$ & $13.49 \%$ \\
\hline
\end{tabular}

Source: compiled by the author

Table 8. Mini-bonds of European football clubs, placed by Tifosy in 2018

\begin{tabular}{|c|c|c|c|}
\hline Club & Country & Amount & Purpose \\
\hline Norwich City & England & $£ 3.5$ million & Development of the academy \\
\hline Pescara & Italy & $€ 2.4$ million & Development of the training facility \\
\hline Frosinone & Italy & $€ 1.5$ million & Stadium reconstruction \\
\hline Stevenage & England & $£ 600$ thousand & Stadium reconstruction \\
\hline
\end{tabular}

Source: compiled by the author on the basis of the data provided by the investment company Tifosy

As can be seen above, the English football club Norwich City managed to raise the biggest amount. In March of 2018 it declared the raising of $£ 3.5$ million from 740 supporters for the development of a children's sports academy. An investor in that case gets a return of $8 \%$ per annum, which consists of 2 parts:

- $5 \%$ - monetary payments;

- $3 \%$ - club credit, which may be used to buy tickets for matches, food and drinks at the stadium, and other goods and tickets for club events.

If within the bonds maturity period Norwich City manages to get into the English Premier League (EPL), the investors will receive a one-time payment of $25 \%$ of the investment amount. Apart from the financial advantage, a supporter-investor gets an opportunity to have his name included on the Wall of Supporters in the club training center.

Thus, mini-bonds are a rather promising financial instrument which affords an opportunity to the club to monetise its relations with supporters. Herewith, it should also be taken into consideration that it is an extremely nonliquid instrument and it does not oblige the club to fulfill normative obligations to the investors related to disclosure of financial information, conducting meetings with management etc.

\section{Share Capital}

Apart from debt financing, companies may raise funds by selling a part of their shares or by an additional share issue. Their owners have the right to participate in management of the company and receiving dividends. However, the shareholders of the majority of football clubs want to manage the club on their own and do not intend to disclose information, thus limiting prospects for placement. The following special types of ordinary shares help to solve this problem:

- non-voting shares - these do not grant the voting right at shareholder meetings;

- $\quad$ subordinated shares - these grant a right to vote, but to a lesser extent than classical ordinary shares;

- low-vote ordinary shares - these grant the right to participate in shareholder meetings only in case of possession of a certain number of shares.

A special feature of preferred shares is the fact that they display all the properties of shares as well as those of bonds. They are recorded on the books as equity capital, however, their owner (as well as the bonds' holder) has a priority right to fixed income in contrast to ordinary shareholders, and usually has no voting right at the shareholder meeting. There are several types of preferred shares. Cumulative shares imply that in case for some reason the dividends on them are not paid in the current reporting period, their amount is accumulated and the company undertakes to pay them in subsequent years. Noncumulative shares do not offer such an option. Also, preferred shares are divided into shares with a fixed return dividend which remains unchanged within the whole period, and with variable dividend whose value depends on the amount of profit. Companies may make a private or public placement of their shares. In the case of a private placement a certain part of business is sold to one investor or a limited group. 
Table 9. A list of European football clubs whose shares are listed on stock exchanges

\begin{tabular}{|c|c|c|c|c|c|}
\hline Club & Country & $\begin{array}{l}\text { Year of } \\
\text { IPO }\end{array}$ & Currency & $\begin{array}{l}\text { Raised amount, } \\
\text { million }\end{array}$ & $\begin{array}{l}\text { Market capitalization as } \\
\text { of 29.03.2019, million }\end{array}$ \\
\hline Brøndby & Denmark & 1990 & DKK & - & 240 \\
\hline Celtic & Scotland & 1995 & GBP & - & 154 \\
\hline Copenhagen & Denmark & 1995 & DKK & - & 1012 \\
\hline Aarhus & Denmark & 1995 & DKK & - & 87 \\
\hline Porto & Portugal & 1998 & EUR & 40 & 16 \\
\hline Ajax & Holland & 1998 & EUR & - & 312 \\
\hline Lazio & Italy & 1998 & EUR & 61 & 81 \\
\hline Aalborg & Denmark & 1998 & DKK & 87 & 35 \\
\hline Sporting & Portugal & 1999 & EUR & 42 & 48 \\
\hline Roma & Italy & 2000 & EUR & 72 & 309 \\
\hline Borussia & Germany & 2000 & EUR & 149 & 751 \\
\hline Juventus & Italy & 2001 & EUR & 143 & 1532 \\
\hline Besiktas & Turkey & 2002 & TRY & 19 & 336 \\
\hline Galatasaray & Turkey & 2002 & TRY & 28 & 653 \\
\hline Fenerbahce & Turkey & 2004 & TRY & 40 & 619 \\
\hline Trabzonspor & Turkey & 2005 & TRY & 33 & 213 \\
\hline AIK & Sweden & 2006 & SEK & - & 59 \\
\hline Benfica & Portugal & 2007 & EUR & 66 & 60 \\
\hline Lyon & France & 2007 & EUR & 89 & 170 \\
\hline Ruch & Poland & 2008 & PLN & 5 & 10 \\
\hline Manchester United & England & 2012 & USD & 234 & 3162 \\
\hline
\end{tabular}

Source: compiled by the author on the basis of Bloomberg data, UEFA report Club Licensing Benchmarking Report, Financial Year 2017

The main advantages of this mechanism are the absence of strict legislative and formal requirements, the fact that all material terms of a transaction are defined independently, rather low costs for preparation, rapidity of the transaction, and further opportunities for raising external financing. The drawbacks include a dependence on a limited group of investors and the furnishing to them of detailed information on the company, and the possible inclusion in the board of directors of the investor's representative.

In case of a public placement, the securities are offered to an unlimited number of investors. It may be an initial public offering (IPO) or a secondary public offering (SPO). In practice, an IPO/SPO pursues two main objectives: to raise funds for company development and to capitalise on the achieved results. This instrument is the most complex one of all mentioned thus far, and it requires a very long and diversified preparation. However, at the same time it is the most promising instrument for a modern football club, considering that this "unlimited" group may consist of its supporters motivated by the wish to be a part of the club. Other advantages of this funding source may include an absence of obligatory payments, no requirement to repay the raised funds, and the raising of the profile of the football club which may have a positive effect on the brand value. The main drawbacks include a complex procedure of making the issue, high expenses for its preparation and the necessary public disclosure of information.

The pioneer in raising external financing is the English football club Tottenham Hotspur, which conducted an 
IPO back in 1983 placing over $40 \%$ of existing shares at the stock exchange. It remained the only public football club for a long time [3].

Subsequently, several dozen European football clubs followed the example of Tottenham, however, for a variety of causes, many of them delisted the shares within a given period. The most relevant example is the delisting of shares of another English club, Arsenal.

In Arsenal's case, in August of 2018, Stan Kroenke, an American entrepreneur, redeemed a $30 \%$ portfolio of shares of the club from the Russian billionaire Alisher Usmanov which amounted to $£ 550$ million $^{4}$. As a result his share in the share capital exceeded $90 \%$ and there arose the obligation to redeem shares from minority shareholders. The total value of the transaction is $£ 600$ million, which makes it the largest one in all of football. It is interesting that just $£ 45$ million (7\%) was paid by Kroenke's own funds. The remaining amount was granted as a credit by Deutsche Bank, which was the American businessman's consultant.

According to the available information as of the end of 2018 there are in circulation shares of 21 European football clubs which belong to the top divisions of their countries (table 9).

For a range of reasons, relations between the football club Manchester United and the stock market deserve close attention. The IPO of 2012 was not the first attempt of the club to go public. Besides, the club managed to raise the maximum amount of funds in the history of football club IPOs and its current market capitalisation substantially exceeds that of its competitors.

Initially the club became public back in 1991, and following an IPO on the London Stock Exchange, it managed to raise over $£ 10$ million. However, more than half of existing shares were not sold and the price went down to $£ 2$, a fall from $£ 8.33$ at the date of offering.

In 2004 club shares started growing due to the purchase of large quantities by the American businessman Malcolm Glazer. He increased his ownership share in the club gradually and by October of 2004 it amounted to 30\%. In May of 2005 Glazer reached an agreement with several shareholders concerning the purchase of their share resulting in his ownership of $75 \%$ of the club shares. This allowed him to restructure the club into a private company. In order to carry out the transaction, Glazer used debt funding. If before the 'takeover' Manchester United had no debts, by 2006 the indebtedness amounted to $£ 558.9$ million. ${ }^{5}$ That aroused supporters' indignation and resulted in strained relations between them and club management.
The current period of shares circulation of the football club Manchester United started in 2012 when the club managed to raise $\$ 233$ million through their IPO. The shares were offered on the New York Stock Exchange, though initially it was planned to do it in Singapore. ${ }^{6}$ In making the IPO, Manchester United placed $166,666,667$ "A" shares on offer, each of which grants 1 shareholder vote and which cannot be converted into any other shares. A part of the placed shares $(8,333,333$ shares) belonged to a selling shareholder and the club obtained no benefit from them. "B" shares, which were not offered under IPO, grant the right to 10 votes and may be converted into " $\mathrm{A}$ " shares. After the placement the amount of " $\mathrm{A}$ " shares represented $24.2 \%$ of the share capital, but their portion of available votes represented only $3.1 \%$. Thus, the club managed to raise funds, while new shareholders gained virtually no influence on the club management.

Manchester United planned to use all the funds raised to repay their debt, that is to redeem and retire bonds. As of June 30,2012 the club's total debt amounted to $£ 436.9$ million. Subsequent to the placement, the debt would have been reduced to $£ 374.3$ million. However, due to the fact that the shares had been sold at a lower price, that goal was not attained. Initially the range of the placement price was established as $\$ 16-\$ 20$ per share but under the influence of market factors, the offering price amounted just to \$14 per share.

Thus, offering shares at a stock exchange helps to get access to the capital of private investors (supporters), but it requires disclosure of information and makes the club value dependent on a range of factors which are hard to predict, and primarily on competitive results. The most important question when shares of a football club are placed is the fair estimation of its value. These issues are addressed in detail in a series of papers by Russian and foreign authors $[5,11,12,13]$. Taking into consideration the specific character of the Russian football business one is hardly to expect such placements in the foreseeable future. For example, even the most long-expected IPOthat of the Moscow club Spartak - will not take place as its principal shareholder declared, because the club will be transferred to the supporters free of charge ${ }^{7}$.

\section{Conclusions}

The phase-by-phase public offering of Russian football clubs is one of the key objectives of the Strategy of Football Development in the Russian Federation (Strat-

\footnotetext{
${ }^{4}$ Phil Serafino, David Hellier. Kroenke to Buy Rest of Arsenal, Ending Tycoons' Soccer Duel // https://www.bloomberg.com/news/ articles/2018-08-07/arsenal-owner-kroenke-agrees-to-buy-usmanov-stake-in-soccer-club

${ }^{5}$ Simon Stone. Man Utd: 10 years of the Glazers - is Old Trafford club better off? // BBC. 12 мая 2015. URL: http://www.bbc.com/sport/ football/32615111

${ }^{6}$ Fiona Lau, Saeed Azhar. Manchester United plans \$1 billion Singapore IPO // Reuters. 16 августа 2011. URL: http://www.reuters.com/article/usmanunited-ipo-idUSTRE77F2BU20110816

${ }^{7}$ https://www.forbes.ru/biznes/378479-fedun-poobeshchal-peredat-stadion-spartaka-bolelshchikam
} 
egy: Football 2020). This indicates that the government realises that when state and local authorities (or government-owned corporations) act as owners and at the same time as sponsors of the majority of clubs, that greatly limits the potential for development of Russian football. Against this background, public share placement seems to be the most promising way to raise funds.

However, the use of this instrument is possible only for the largest Russian clubs which are simultaneously most popular in Europe, most experienced in participation in international competitions, and which have a business model closest to the market model. Examples of such clubs are FC Spartak, FC Zenit, FC Lokomotiv, FC CSKA and FC Krasnodar.

Public share placment is typical for the majority of clubs where there is a range of affiliated legal entities for which a certain part of profits/losses is allocated. At the same time, various agreements for rendering services are concluded between such legal entities.

The Moscow Stock Exchange should be used for IPOs and it can provide opportunities to purchase clubs' shares to a wide range of Russian investors, as well as to foreign investors who have access to trading.

The use of this financial instrument will give Russian clubs a wider access to funds existing in the stock market, allow them to acquire market value, improve brand awareness and the club's image. It will also help to provide conditions for the withdrawal from business of the existing shareholders and get an opportunity for staff recruitment, retention and reward by transferring to them a portion of the available shares. The main drawbacks of this method of raising funds are high time and cash expenditures, potential loss of control over the club, administrative and regulatory confidentiality, and the necessity to meet the requirements as regards the corporate management etc.

For the purpose of diversification of the sources of business funding, the football clubs should consider the opportunity to use debt financing instruments, i.e. placement of bonds. As in the case of IPO and for the same reasons this instrument of financing is potentially available just to a limited number of clubs: FC Spartak, FC Zenit, FC Lokomotiv, FC CSKA and FC Krasnodar.

The most promising method of raising funds for Russian clubs may be the placement of mini-bonds. This instrument is available to every club, since each of them has at least some supporters who are ready to invest in their favourite club. The amount of raised funds, the coupon rate, and other placement parameters in this case are defined by ordinary negotiations between the club and a group of supporters.

Offering of shares/bonds of Russian football clubs to a wide range of investors may substantially increase the level of diversification of funding sources and reduce clubs' dependence on the funds received from public authorities and government-owned corporations. As a result, the clubs will be able to conduct operations as independent business units and the risks that deterioration in the macroeconomic environment in the country will lead to a significant reduction of the budget allocated to the club will fall by the wayside. This latter aspect is the primary problem facing Russian professional football and the examples of Saturn, Tosno, Amkar and Anzhi confirm it. Entry to the debt market by way of public shares is not just a path towards raising funds, but also an opportunity for clubs to improve the company management structure, to provide insight into the value of the business (inter alia for shareholders themselves), and to use the best management practices [7]. This may prove an interesting prospect both for the existing private owners of Russian football clubs, and from the point of view of privatising clubs in general.

The strengthening of the financial standing of Russian clubs will be manifested in a positive way according to competitive results as well- this will result in an upsurge in the interest of all stakeholders in the results of competition: investors, players, coaches and other concerned parties.

The most important positive result may be an improvement in the status of Russian football clubs and a strengthening of their brands. After all, a successful IPO or successful placement of bonds de facto means that a certain club has achieved such a stage of development that it is of interest not only to the existing team owners but also to independent investors. This may serve to raise additional funds from new sponsors (including international ones) and hence, it will increase revenues.

Finally, a successful placement of shares or bonds will set a precedent for further, more accomplished co-operation between football clubs and financial markets, because both parties will already have experience which will allow them to maximise the effectiveness of such co-operation.

\section{References}

1. Football development strategy in the Russian Federation (“Football 2020" strategy). URL: https:// rfs.ru/knowledge-base/1/documents (In Russ.).

2. The European club footballing landscape. Club licensing benchmarking report. Financial year 2017. Nyon: UEFA; 2017. 118 p. URL: https://ru.uefa.com/ MultimediaFiles/Download/OfficialDocument/ uefaorg/Clublicensing/02/58/99/65/2589965_ DOWNLOAD.pdf

3. Solntsev I.V. Finance in football. Moscow: Prospekt; 2019. 320 p. (In Russ.).

4. European stadium insight 2011: Prospects for football stadium development and commercialization across Europe. Amstelveen: KPMG; 2011. 36 p.

5. Alexander D.L., Kern W. The economic determinants of professional sports franchise values. Journal of Sports Economics. 2004;5(1):51-66. DOI: $10.1177 / 1527002503251715$ 
6. Sabic P. What's the score? S\&P capital IQ's credit football league. 2014. URL: https://www.academia. edu/8725082/S_and_P_Capital_IQ_Credit_Football_ League

7. Vorob'ev A.I., Solntsev I.V. Building a rating system in modern football. Vestnik Rossiiskogo ekonomicheskogo universiteta im. G.V. Plekhanova = Vestnik of the Plekhanov Russian University of Economics. 2014;(3):110-120. (In Russ.).

8. Deloitte football money league. 2019. Bullseye. London: Deloitte; 2019.60 p. URL: https://www2. deloitte.com/content/dam/Deloitte/uk/ Documents/ sports-business-group/deloitte-uk-deloitte-footballmoney-league-2019.pdf

9. UEFA club licensing and financial fair play regulations. Nyon: UEFA; 2018. 116 p. URL: https:// www.uefa.com/MultimediaFiles/Download/ Tech/uefaorg/General/02/56/20/15/2562015_ DOWNLOAD.pdf

10. Official website of “Tifosy”. URL: https://www.tifosy. $\mathrm{com} /$

11. Solntsev I.V. Developing a unified approach for evaluation of football clubs. Korporativnye finansy = Journal of Corporate Finance Research. 2018;12(1):7790. (In Russ.). DOI: 10.17323/j.jcfr.2073-

0438.12.1.2018.77-90

12. Solntsev I.V. Estimation of the cost of a sports club using the "Zenit" football club as an example. Imushchestvennye otnosheniya $v$ Rossiiskoi Federatsii = Property Relations in the Russian Federation. 2018;(11):52-64. (In Russ.).

13. Markham T. What is the optimal method to value a football club? SSRN Electronic Journal. 2013. DOI: $10.2139 /$ ssrn. 2238265

14. Bogatyrev S.Yu. Corporate finance: Valuation. Moscow: RIOR, Infra-M; 2018. 164 p. (In Russ.).

15. Russian Premier League. A comprehensive study of the economics of Russian football: Season-2018/2019. Moscow: PWC; 2018. 44 p. URL: https://www.pwc. $\mathrm{ru} / \mathrm{ru} /$ sports/pwc-rpl-research-season-18-19.pdf (In Russ.).

16. Nationwide football development strategy in the Russian Federation for the period up to 2030. Approved by Resolution No. 8 of the RFU Conference of April 8, 2017. URL: https://rfs.ru/knowledgebase/5/documents (In Russ.).

17. Solntsev I.V. Evaluation of the effectiveness of IPO transactions on the example of football clubs. Imushchestvennye otnosheniya $v$ Rossiiskoi Federatsii = Property Relations in the Russian Federation. 2016;(3):75-84. (In Russ.).
18. Annual review of football finance 2018. Roar power. London: Deloitte; 2018. 36 p. URL: https://www2. deloitte.com/content/dam/Deloitte/uk/ Documents/ sports-business-group/deloitte-uk-sbg-annualreview-of-football-finance-2018.PDF

19. Ecer F., Boyukaslan A. Measuring performances of football clubs using financial ratios: The gray relational analysis approach. American Journal of Economics. 2014,4(1):62-71. DOI: 10.5923/j. economics.20140401.06

20. Official website of FitchRatings. URL: https://www. fitchratings.com/

21. Official website of KPMG Football Benchmark. URL: https://www.footballbenchmark.com/home

22. Official website of Moody's. URL: https://www. moodys.com/

23. Official website of Reuters. URL: https://www.reuters. $\mathrm{com} /$

24. Official website of "SPARK-Interfax". URL: http:// www.spark-interfax.ru/

25. Official website of Standard \& Poors. URL: https:// www.standardandpoors.com/ 